\title{
Migration, remittances, and health care utilization in Ecuador
}

\author{
Daniel F. López-Cevallos ${ }^{1}$ and Chunhuei Chi ${ }^{2}$
}

Suggested citation López-Cevallos DF, Chi C. Migration, remittances, and health care utilization in Ecuador. Rev Panam Salud Publica. 2012;31(1):9-16.

ABSTRACT Objective. To examine the relationship between migration and migrant remittances and health care utilization in Ecuador, and to identify any potential equalizing effects.

Methods. Using data from the 2004 National Demographic and Maternal $\mathcal{E}$ Child Health Survey (ENDEMAIN), a multilevel multivariate analysis was conducted to assess the relationship of two migrant predictors (households with an international migrant; use of migrant remittances) with use of preventive care, number of curative visits, hospitalization, and use of antiparasitic medicines. Relevant predisposing, enabling, and need factors were included following Andersen's Model of Health Care Utilization Behavior. Interaction terms were included to assess the potential equalizing effects of migration and remittances by ethnicity, area of residence, and economic status.

Results. Migrant predictors were strongly associated with use of antiparasitic medicines, and to a lesser extent, with curative visits, even after adjusting for various predisposing, enabling, and need factors. Interaction models showed that having an international migrant increased use of these services among low-income Ecuadorians (quintiles 1 and 2). No significant relationship was found between migrant predictors and use of preventive services.

Conclusions. Migration and remittances seem to have an equalizing effect on access to antiparasitic medicines, and to a lesser extent, curative health care services. Health care reform efforts should take into account the scope of this effect when developing public policy.

Key words Migration; emigration and immigration, trends; health services accessibility; multilevel analysis; national health policy; Ecuador.

Human mobilization across national borders, though not a new phenomenon, is increasingly being recognized as an important factor in the current economic globalization scheme. More specifically, economists and policymakers are interested in the vast amounts of money flowing from migrants' host to home

1 Community Health, Western Oregon University, Monmouth, Oregon, United States of America. Send correspondence to Daniel Lopez-Cevallos, lopezced@wou.edu

2 International Health Program, Department of Public Health, Oregon State University, Corvallis, Oregon, United States of America. countries-most often from high-income countries to those of middle/lowincome. Migrant remittances reached US\$ 167 billion in 2005 (1), with more than half being sent to middle/lowincome countries (2).

Due to the recent global economic crisis, remittances have fallen from US\$ 336 billion in 2008 to US\$ 316 billion in 2009 . Nevertheless, remittances accounted for $1.9 \%$ percent of GDP for all developing countries in 2008, and $5.9 \%$ for lowincome countries (3). In Latin America, remittances almost tripled between 2001 and 2008, from US\$ 24 billion to US\$ 69 billion (4). This amount is more than what Latin American countries receive in development assistance and foreign direct-investment together. Yet, there is a good portion of remittances being sent outside the formal financial system, particularly in Latin America, where migrants rely on international moneytransfer companies, local operators, and / or hand-carriers (5).

On the other hand, migrant networks in the host countries seem to influence a number of migratory outcomes, such as wages and working conditions, patterns of investment, and the sending of 
remittances $(6,7)$. These international transfers from migrants to their home communities have been recognized as playing a significant role in the health and well-being of recipients by financing the purchase of food, clothing, and housing; education expenses; land and businesses investments $(8,9)$; and health care services $(10,11)$. Recent studies in El Salvador and the Philippines have shown that recipient households use these resources to make crucial investments for the future, which lead to increased child schooling, reduced child labor, and greater entrepreneurial activity $(12,13)$. A 2007 study, that included Ecuador, found that remittances had a positive impact on poverty reduction at the household level (14). Considering the social determinants of health, these investments can have great impact on individual and population health outcomes (15).

Previous research shows that a country's political atmosphere influences social inequalities and health indicators (16). The economic crisis of the 1990s created a deep political, economic, and social crisis in Ecuador $(17,18)$. The resulting chaos led to a massive emigration movement. In 1999-2008, approximately 1 million Ecuadorians left the country (19). Ecuador's growing migrant community, mainly hosted by Italy, Spain, and the United States, has placed migrant remittances as the second largest source of national income (petroleum being the first), rising from US\$ 200 million in 1993, to US\$ 1.4 billion in 2001, and to US\$ 3.1 billion in $2008(20,21)$.

Various scholars have pointed out the social and economic implications of the money that migrants send back to their families (5, 12, 13, 22, 23). According to the literature, the potential effects of emigration are described as twofold: (a) the flow of monetary funds (remittances) may help to relieve income constraints when seeking social services (e.g., health care); and (b) the exchange of resources in the origin communities may influence family structure (gender roles), social networks, and information sources (e.g., healthy lifestyles) (24). Along these lines, having migrants in a person's or family's social network may expose them to destination norms and practices (without having migrated) that are more persuasive since they come from a trusted source. The ideas, behaviors, identities, and social capital that flow from sending-to-receiving communities have been labeled as "social remittances" (25). There are a few examples of both of these effects in the literature, mostly from research in Mexico. Mexican families with a migrant relative had higher birth weights than those families without (26). In Guatemala a similar effect was found regarding prenatal access and utilization (10). Another study found that in Mexico, remittances allowed uninsured families to access health care employerbased insurance coverage (11).

Little research, however, exists on the impact of remittances on health in other Latin American countries, such as Ecuador, despite marked inequalities in health care utilization $(27,28)$ and health outcomes (29). Therefore, the present study was undertaken to evaluate the role of migration and remittances on health services utilization in Ecuador. Building upon their previous research on how social and economic inequalities affect health services utilization in Ecuador (27), the authors examined the influence of remittances on low-income, indigenous, rural households in Ecuador.

\section{METHODS}

\section{Study design}

This cross-sectional study-using Andersen's Model of Health Care Services Utilization Behavior as a conceptual framework (30)-analyzed data from the 2004 Demographic and Maternal and Child Health Survey (ENDEMAIN) of Ecuador (31) to determine how a migrant relative and migrant remittances may be influencing a family's health care utilization.

\section{Data analysis}

Based on a nationally-representative sample of households in Ecuador, the principal objective of ENDEMAIN is to obtain information on demographic dynamics and the health status of women and children (31). ENDEMAIN 2004 also included an international migration module and a health services utilization module.

For data entry, ENDEMAIN 2004 used CS Pro (Census and Survey Processing System, United States Census Bureau, Washington DC, United States). For statistical analysis, ENDEMAIN 2004 used SAS (SAS Institute, Inc., Cary, North
Carolina, United States) and IBM SPSS Statistics software, version 10 (SPSS Inc., an IBM company, Chicago, Illinois, United States) (31). ENDEMAIN 2004 used a multistage clustering design to provide a nationally-representative sample of 28908 households. The 2001 National Census was utilized as the sampling frame for selecting individual, non-institutionalized households within census segments.

\section{Survey instrument}

The ENDEMAIN 2004 survey instrument used for this study was paperbased and interviewer-administered. Two separate questionnaires had been applied to two different sub-samples: (a) in 10813 households, an interview on sexual and reproductive health was completed with a female member of reproductive age; (b) in 10985 households, an interview on health utilization and expenditures was completed with an adult member. The latter was the dataset used by the present study. The response rate was $88.7 \%$ (31).

Since ENDEMAIN did not collect marital status data on those less than 12 years of age, the analysis for use of preventive, curative, and hospitalization care focused on participants 12 years or older. In turn, use of antiparasitic medicines pertained only to those less than 15 years of age. "Household" was defined as only those members of the family living under one roof; it did not include any family member that had migrated. The migrants were only captured by the international migration module of the ENDEMAIN 2004.

\section{Measures}

Utilization of health care services. Both preventive and curative measures of realized utilization were employed in the study. The ENDEMAIN 2004 included one question regarding preventive care:

- Have you visited a physician for a preventive appointment in the last 30 days?

It included three questions on curative care:

- Have you visited a physician for a curative appointment in the last 30 days?

- Have you been hospitalized in the last 12 months? 
- Have you taken antiparasitic medicine in the last 12 months?

All of these variables were dichotomous (yes/no), except for the one regarding curative appointments, which was a count of how many.

Migration predictors. Building on previous research (10), two predictors were identified as enabling factors: (a) Whether the household had a member(s) who had migrated (migrants); and (b) how migrant remittances were used (remuse). The remuse predictor had four possible categories: health and education; other purposes; didn't know/no answer; and, no migrants. Originally, question no. 812 of the ENDEMAIN 2004 asked what the two main uses of migrant remittances were in the household. The "remuse predictor," however, was created as a combination of two variables extracted from question 812. Since the focus of this study was health care utilization, the original variables were re-coded into the following categories: health and education (category 4); other purposes (category 1, which included: pay debts; daily expenses; buy, build, or repair house; buy land, bank deposit, other); and doesn't know/no answer (category $0)$. Then, the two variables were added to obtain a summary variable with the following ranges: categories $4-5$ (i.e., the two main uses of remittances were category 4 , or category $4+$ category 1 = category 5); categories 1-2 (the respondent knew of only one use or the two main uses were both from category 1); and category 0 . Finally, these ranges were transformed back into these categories: categories $4-5$ became category 2 "health and education"; categories 1-2 became category 1 "other purposes"; and 0 remained "didn't know/no answer." The final predictor (remuse) also included the category "no migrants."

Other predictors. Besides the key variables mentioned above, other explanatory variables were considered in this study, classified according to Andersen's model. Predisposing factors included age, sex, ethnicity, and marital status. For use of antiparasitic medicines, the head-ofhousehold's sex and marital status were included. Enabling factors consisted of area of residence, assets quintile, consumption quintile, educational level, and health insurance affiliation. For use of an- tiparasitics, head-of-household's educational level was included. Need was measured as the number of health problems.

ENDEMAIN 2004 asked individuals if they had health problems during the previous 30 days, and to mention the two most important problems (31). From these questions, a summary variable was created to identify the number of health problems mentioned by the participants (none, one problem, and two problems). Fifty percent of study participants had at least one health problem. Respiratory $(25 \%)$, chronic $(7 \%)$, digestive $(6 \%)$, and neurologic $(5 \%)$ were the four main health problems that affected the Ecuadorian study population (31).

\section{Statistical analysis}

Summary statistics for all discrete and continuous variables were calculated. Tables 1 and 2 summarize the variables used in the analysis for use of preventive care, number of curative visits, hospitalization, and use of antiparasitic medicines, respectively. Since ENDEMAIN 2004 sampling frame had four levelsindividual $(n=33387)$; household ( $n=10$ 985); census segment $(n=692)$; and province/region ( $n=17-$ multilevel models were used to examine the influence of migrant predictors on utilization of health care, adjusting for other predisposing, enabling, and need factors. In doing so, this study recognized the importance of accounting for clustering in such a complex sample design (32, 33). The multilevel structure allowed for the simultaneous analysis of data at the various levels within which data were originally collected in ENDEMAIN 2004. A number of recent studies used multilevel modeling to assess health care utilization $(27,34,35)$.

Preliminary analysis to assess the relevance of a four-level model was conducted. By fitting a non-conditional (empty, null) model, variance was partitioned across levels to assess its statistical significance and contribution to overall variance. In the case of hospitalization, the non-conditional model showed no significant variation at the household level. Consequently, no migrant predictors could be entered in the regression models. Further models were fitted for use of preventive services, antiparasitic medicines, and curative services only. Models were fitted using the iterative generalized least-squares maximum-likelihood estimator (36). For each model, variables were assigned to each significant level (as they were originally collected) to build conditional models in a sequential order. The first conditional model (model 1) included only the migration predictor; while the second model (model 2) added various predisposing, enabling, and need predictors in the fixed component. Both models included a random variance component at the household, census segment, and province/region levels. It should be noted that in the case of preventive services and antiparasitic medicines, variation was higher at the household level. In other words, both outcomes varied significantly across households, even after controlling for other covariates. This also suggests that there might be other household-level relevant factors not included in the models.

To evaluate the equalizing role of migration and remittances among lowincome, rural, and indigenous Ecuadorians, the multivariate models included the two predictors (migrants, remuse), plus the following five interaction terms, one at a time: ethnicity; area of residence; assets quintile; consumption quintile; and ethnicity with area of residence.

Stata ${ }^{\circledR}$ Statistical Software, release 9.2 (StataCorp LP, College Station, Texas, United States) was used for data preparation; while MLwiN 2.02 (Center for Multilevel Modeling, Bristol, United Kingdom) was used to fit all multilevel models.

\section{RESULTS}

Table 3 shows the multilevel regression estimates for the association between having a migrant in the household and each outcome variable, following Andersen's Model of Health Care Utilization Behavior (30). For use of preventive care services, both bivariate and multivariate multilevel models showed no significant relationship with having a migrant in the household (odds ratio $[\mathrm{OR}]=1.02$, $95 \%$ confidence interval $[95 \% \mathrm{CI}]=0.83-$ 1.27; $\mathrm{OR}=0.85,95 \% \mathrm{CI}=0.69-1.05$, respectively). The constant in model 2 represented a married mestizo male, 35 years of age, residing in an urban area, belonging to the highest assets and consumption quintile categories, with no migrants in the household, a college education, and health insurance, who reported no health problems at the time of 
TABLE 1. Unweighted summary statistics of demographic, migration, and health care utilization variables among those 12 years of age or more, National Demographic and Maternal and Child Health Survey, Ecuador, 2004

\begin{tabular}{|c|c|c|}
\hline Variable & $\begin{array}{c}\text { Percent }{ }^{\mathrm{a}} \\
(n=33532)\end{array}$ & Level \\
\hline \multicolumn{3}{|l|}{ Predisposing factors } \\
\hline Age & 35.4 years $( \pm 18.5)^{\mathrm{b}}$ & Individual \\
\hline Female & 50.8 & Individual \\
\hline Ethnicity & & Household \\
\hline Mestizo & 85.7 & \\
\hline Indigenous & 8.6 & \\
\hline Others & 5.7 & \\
\hline Marital status & & Individual \\
\hline Living w/partner & 15.5 & \\
\hline Married & 37.2 & \\
\hline Separated/divorced & 5.2 & \\
\hline Widow & 4.1 & \\
\hline Single & 37.9 & \\
\hline \multicolumn{3}{|l|}{ Enabling factors } \\
\hline Households with international migrant & 9.8 & Household \\
\hline Use of migrant remittances & & Household \\
\hline Health and education & 2.9 & \\
\hline Other uses & 3.9 & \\
\hline Doesn't know/no answer & 3.0 & \\
\hline No migrants & 90.2 & \\
\hline Area of residence & & Census segment \\
\hline Urban & 51.6 & \\
\hline Rural & 48.4 & \\
\hline Assets quintile & & Household \\
\hline 1 & 22.5 & \\
\hline 2 & 20.5 & \\
\hline 3 & 19.0 & \\
\hline 4 & 18.8 & \\
\hline 5 & 19.2 & \\
\hline Consumption quintile & & Household \\
\hline 1 & 23.0 & \\
\hline 2 & 20.5 & \\
\hline 3 & 19.4 & \\
\hline 4 & 19.0 & \\
\hline 5 & 18.0 & \\
\hline Educational level & & Individual \\
\hline None & 8.3 & \\
\hline Elementary & 45.0 & \\
\hline High School & 35.5 & \\
\hline College & 11.2 & \\
\hline Doesn't know/no answer & 0.1 & \\
\hline Insurance & & Individual \\
\hline Insured & 22.6 & \\
\hline Uninsured & 77.4 & \\
\hline \multicolumn{3}{|l|}{ Need } \\
\hline Health problems & & Individual \\
\hline No problems & 52.8 & \\
\hline One problem & 40.1 & \\
\hline Two problems & 7.1 & \\
\hline \multicolumn{3}{|l|}{ Utilization } \\
\hline Preventive care use & 4.6 visits & Individual \\
\hline Curative care visits & 0.2 visits $( \pm 0.48)^{b}$ & Individual \\
\hline Hospitalizations & 3.0 admissions & Individual \\
\hline
\end{tabular}

a Percentages unless otherwise indicated.

b Standard deviation.

the survey. This comparison group had a $9.6 \%$ probability of using preventive services. Interaction models showed that ethnicity and area of residence played a role in accessing these health services. Households of other ethnicities, including Afro-Ecuadorians, seemed to ben- efit from having a migrant $(\mathrm{OR}=2.15$, $95 \% \mathrm{CI}=1.28-3.63)$, especially if living in a rural area $(\mathrm{OR}=2.93,95 \% \mathrm{CI}=$ 0.81 - 10.57), although the interaction was not statistically significant.

Having a migrant in the household was positively associated with using antiparasitic medicine, even after adjusting for predisposing, enabling, and need factors $(\mathrm{OR}=1.46,95 \% \mathrm{CI}=1.23-1.73$; $\mathrm{OR}=1.34,95 \% \mathrm{CI}=1.16-1.55$, respectively). The constant in model 2 represented a mestizo boy, 7 years of age, living in an urban area, belonging to the highest assets and consumption quintile categories, with health insurance, who reported no health problems, and whose household head is male, married, and has a college education. This comparison group had a $63.5 \%$ probability of using antiparasitic medicine. No significant interactions were found for this outcome variable.

Having a migrant in the household was positively associated with the number of curative care visits $(\beta=0.110$, $P<0.05)$. After controlling for various predisposing, enabling, and need factors, such relationship was not statistically significant. However, interaction models showed that the lowest-income households increased their utilization of curative services with having a migrant ( $\beta=0.268, P<0.10$ for consumption quintile 1 ; and $\beta=0.240, P<0.10$ for assets quintile 1 ).

Table 4 presents the results of the association between the use of migrant remittances and health care services utilization. Similar to the previous migration predictor, no significant association was found for preventive care, even after including other predictors and interaction terms. For antiparasitic medicines, use of remittances for education and health did not significantly increase use for all households. However, remittances utilized for other purposes (e.g., to pay debts; daily expenses; buy, build, or repair house; buy land, bank deposit, etc.) were significantly associated with use of antiparasitic medicines, even after adjusting for predisposing, enabling, and need factors $(\mathrm{OR}=1.55,95 \% \mathrm{CI}=1.24-$ $1.94 ; \mathrm{OR}=1.45,95 \% \mathrm{CI}=1.17-1.80$, respectively). This was particularly true for indigenous households $(\mathrm{OR}=2.66$, $95 \% \mathrm{CI}=1.57-4.51)$. Further interaction models showed that remittances used for education and health significantly increased use of parasitic medicines for low-income $(\mathrm{OR}=2.19,95 \% \mathrm{CI}=1.38$ $3.48 ; \mathrm{OR}=2.11,95 \% \mathrm{CI}=1.03-4.32$ for consumption quintiles 1 and 2, respectively) and rural $(\mathrm{OR}=1.60,95 \% \mathrm{CI}=$ 1.12 - 2.28) Ecuadorians.

Allocating remittances for education and health or other purposes had a 
TABLE 2. Unweighted summary statistics of demographic, migration and use of antiparasitic medicines among those 14 years of age or less, National Demographic and Maternal and Child Health Survey, Ecuador, 2004

\begin{tabular}{|c|c|c|}
\hline Variable & $\begin{array}{c}\text { Percenta } \\
(n=16581)\end{array}$ & Level \\
\hline \multicolumn{3}{|l|}{ Predisposing factors } \\
\hline Age & 7.1 years $( \pm 4.2)^{b}$ & Individual \\
\hline Female & 49.6 & Individual \\
\hline Ethnicity & & Household \\
\hline Mestizo & 83.2 & \\
\hline Indigenous & 10.6 & \\
\hline Others & 6.2 & \\
\hline Female household head & 14.9 & Household \\
\hline Household head marital status & & Household \\
\hline Living with partner & 26.6 & \\
\hline Married & 58.5 & \\
\hline Separated/divorced & 7.4 & \\
\hline Widow & 4.9 & \\
\hline Single & 2.6 & \\
\hline \multicolumn{3}{|l|}{ Enabling factors } \\
\hline Households with international migrant & 8.9 & Household \\
\hline Use of migrant remittances & & Household \\
\hline Health and education & 3.1 & \\
\hline Other uses & 3.5 & \\
\hline Doesn't know/no answer & 2.3 & \\
\hline No migrants & 91.1 & \\
\hline Area of residence & & Census segment \\
\hline Urban & 47.7 & \\
\hline Rural & 52.3 & \\
\hline Assets quintile & & Household \\
\hline 1 & 26.7 & \\
\hline 2 & 23.1 & \\
\hline 3 & 19.8 & \\
\hline 4 & 16.8 & \\
\hline 5 & 13.6 & \\
\hline Consumption quintile & & Household \\
\hline 1 & 28.7 & \\
\hline 2 & 22.9 & \\
\hline 3 & 19.7 & \\
\hline 4 & 16.6 & \\
\hline 5 & 12.1 & \\
\hline Household head educational level & & Household \\
\hline None & 8.3 & \\
\hline Elementary & 55.8 & \\
\hline High School & 26.0 & \\
\hline College & 9.9 & \\
\hline Doesn't know/no answer & .1 & \\
\hline Insurance & & Individual \\
\hline Insured & 11.7 & \\
\hline Uninsured & 88.3 & \\
\hline \multicolumn{3}{|l|}{ Need } \\
\hline Health problems & & Individual \\
\hline No problems & 54.9 & \\
\hline One problem & 41.9 & \\
\hline Two problems & 3.2 & \\
\hline \multicolumn{3}{|l|}{ Utilization } \\
\hline Use of antiparasitic medicines & 59.5 & Individual \\
\hline
\end{tabular}

positive association with number of curative care visits in bivariate analyses $(\beta=0.143, P<0.01$; and $\beta=0.124$, $P<0.10$, respectively). Multivariate models showed a change of direction for education and health $(\beta=-0.107$, $P<0.10)$ and loss of statistical signifi- cance for other purposes $(\beta=0.040, P$ $>0.10)$. Interaction models showed that utilization of curative services increased when using remittances for other purposes among households with limited assets $(\beta=0.402, P<0.05$ for assets quintile 1).

\section{DISCUSSION}

Based on a nationally-representative cross-sectional sample of Ecuador, this study was relevant to exploring the relationship between migrant remittances and utilization of health services and contributing to the limited literature on the link between remittances and health. The strongest association was found between migrant predictors and use of antiparasitic medicines. Having a migrant in the household produced a $6.5 \%$ increase in the probability of using antiparasitics in households with children 14 years of age or younger. Using remittances for education and health increased use of antiparasitics for lowincome and rural Ecuadorians, while use of curative services was higher among low-income households that had a migrant. The significant impact of having a migrant may imply that there is a process of "diffusion" of health care concerns (10), i.e., raising awareness of the importance of treating parasitic diseases.

Certainly at the time that the survey was conducted, it seemed the population was more focused on using remittances to pay for day-to-day needs, including urgent medical issues, and not on longer-term health promotion and disease prevention measures. This observation is corroborated by the significant effect of allocating remittances to other purposes (37) and previous research in Mexico (38) that showed migrant remittances were positively associated with primary care expenditures.

It is important to mention that ENDEMAIN 2004 also revealed that pharmacies were the main source of antiparasitic medicines (36\%), followed by the National School Health Program (Programa de Atención Escolar, 17\%), the Ministry of Health of Ecuador (16\%), and private physicians (15\%) (31). The considerable proportion of participants obtaining antiparasitics at the pharmacy may suggest that parents tend to turn to pharmacists, rather than physicians, to avoid paying the extra consultation fees and waiting times. Note that antiparasitic medicines in Ecuador are relatively affordable (in 2010, two tablets of Albendazole $400 \mathrm{mg}$, the usual dose of a common antiparasitic, cost less than half of US\$1).

In general, it seems that emigration and migrant remittances are improving access to antiparasitic medicines and curative health care services (10), particu- 
TABLE 3. Multilevel weighted estimates of the association between household migrants and health care utilization, National Demographic and Maternal and Child Health Survey, Ecuador, 2004

\begin{tabular}{|c|c|c|c|c|c|c|c|c|c|c|c|c|}
\hline \multirow[b]{2}{*}{ Parameters } & \multicolumn{4}{|c|}{ Preventive care use $^{\mathrm{a}}$} & \multicolumn{4}{|c|}{ Antiparasitic medicines $^{a}$} & \multicolumn{4}{|c|}{ No. of curative care visits ${ }^{b}$} \\
\hline & $\begin{array}{l}\text { Model } 1 \\
(\mathrm{SE})^{\mathrm{c}}\end{array}$ & $P$ & $\begin{array}{l}\text { Model } 2^{\mathrm{d}} \\
\text { (SE) }\end{array}$ & $P$ & $\begin{array}{c}\text { Model } 1 \\
\text { (SE) }\end{array}$ & $P$ & $\begin{array}{l}\text { Model } 2^{\mathrm{e}} \\
\text { (SE) }\end{array}$ & $P$ & $\begin{array}{l}\text { Model } 1 \\
\text { (SE) }\end{array}$ & $P$ & $\begin{array}{l}\text { Model } 2^{\mathrm{d}} \\
(\mathrm{SE})\end{array}$ & $P$ \\
\hline Households with migrant member(s) & $\begin{array}{c}0.024 \\
(0.108)\end{array}$ & $N S^{\dagger}$ & $\begin{array}{c}-0.159 \\
(0.105)\end{array}$ & NS & $\begin{array}{c}0.377 \\
(0.086)\end{array}$ & $<0.01$ & $\begin{array}{c}0.293 \\
(0.075)\end{array}$ & $<0.01$ & $\begin{array}{c}0.110 \\
(0.056)\end{array}$ & $<0.05$ & $\begin{array}{c}-0.038 \\
(0.051)\end{array}$ & NS \\
\hline \multicolumn{13}{|l|}{ Random } \\
\hline Level 4: province/region & $\begin{array}{c}0.081 \\
(0.033)\end{array}$ & $<0.05$ & $\begin{array}{c}0.053 \\
(0.028)\end{array}$ & $<0.1$ & $\begin{array}{c}0.065 \\
(0.028)\end{array}$ & $<0.05$ & $\begin{array}{c}0.078 \\
(0.029)\end{array}$ & $<0.05$ & $\begin{array}{c}0.033 \\
(0.009)\end{array}$ & $<0.01$ & $\begin{array}{c}0.022 \\
(0.011)\end{array}$ & $<0.1$ \\
\hline Level 2: household & $\begin{array}{c}2.793 \\
(0.923)\end{array}$ & $<0.01$ & $\begin{array}{l}2.371 \\
(0.606)\end{array}$ & $<0.01$ & $\begin{array}{l}1.210 \\
(0.049)\end{array}$ & $<0.01$ & $\begin{array}{c}1.256 \\
(0.054)\end{array}$ & $<0.01$ & $\begin{array}{c}0.538 \\
(0.013)\end{array}$ & $<0.01$ & $\begin{array}{c}0.152 \\
(0.044)\end{array}$ & $<0.01$ \\
\hline
\end{tabular}

a A four-level binomial logit model (IGLS, MQL1) was fitted for "preventive care use" and "antiparasitic medicines."

b A four-level Poisson model (IGLS, PQL1) was fitted for "number of curative care visits."

c Standard error.

d Adjusted for predisposing, enabling, and need factors (see Table 1).

e Adjusted for predisposing, enabling, and need factors (see Table 2).

${ }^{f} \mathrm{NS}=$ not significant.

TABLE 4. Multilevel weighted estimates of the association between migrant remittances and health care utilization, National Demographic and Maternal and Child Health Survey, Ecuador, 2004

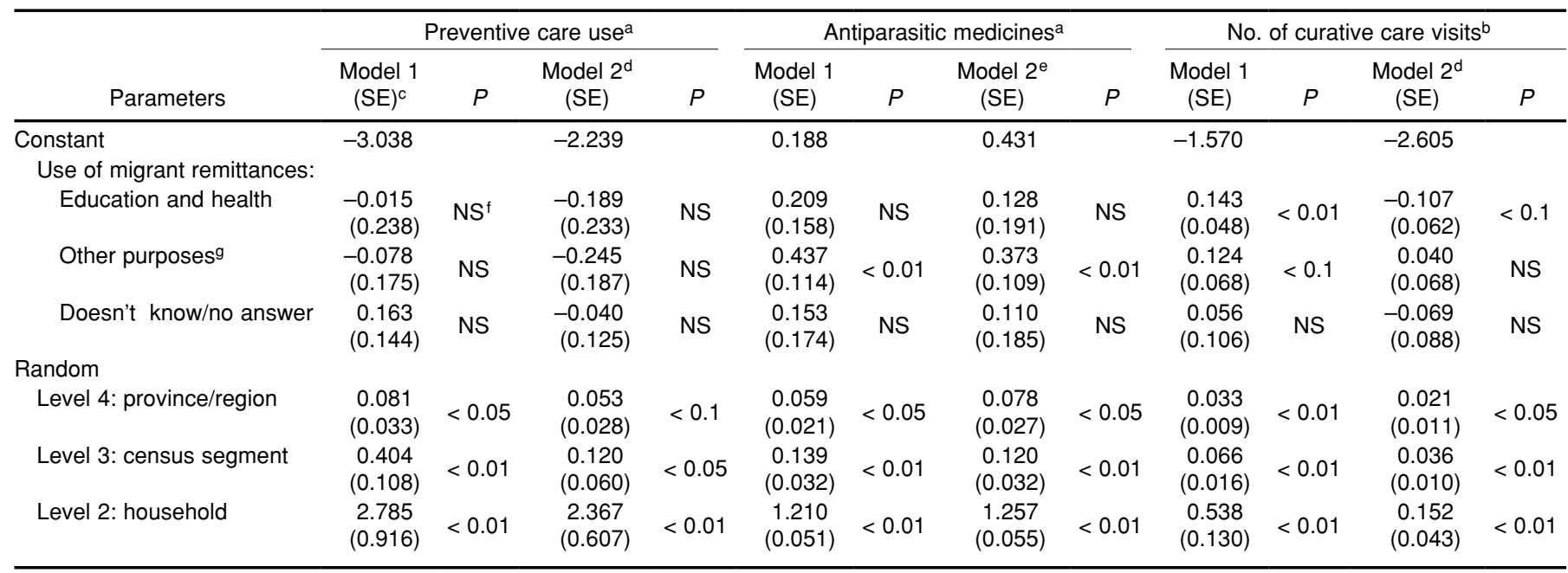

a A four-level binomial logit model (IGLS, MQL1) was fitted for Preventive Care use and Antiparasitic Medicines.

${ }^{b}$ A four-level Poisson model (IGLS, PQL1) was fitted for Number of Curative Care Visits.

c Standard error.

d Adjusted for predisposing, enabling, and need factors (see Table 1).

${ }^{\text {e }}$ Adjusted for predisposing, enabling, and need factors (see Table 2).

f $\mathrm{NS}=$ not significant.

g Pay debts; daily expenses; buy, build, or repair house; buy land, bank deposit, other.

larly for low-income households. The additional income for an Ecuadorian "migrant" household becomes particularly relevant, given that $95 \%$ of health care expenditures are out-of-pocket (31). The current global trend of reduction in remittances (39) could negatively affect migrant families' ability to pay for the more expensive health services. Similarly, another study (26) found that remittances were most likely used on pay-for-fee services, particularly among uninsured families.

Policymakers should consider incorporating the remittances dimension into development and health care financial planning. For future studies, the decrease in remittances resulting from the current global recession needs to be taken into account. Interestingly, how- ever, a recent report showed that Mexican and Ecuadorian migrants in the United States have not significantly decreased remittances in 2008-2009 (40).

The following limitations should be considered when interpreting the findings of this study. First, the selection of variables was limited to those collected by ENDEMAIN 2004. Namely, this study was unable to isolate the influ- 
ence of allocating remittances to health care (ENDEMAIN asked about use of remittances for education and health combined). However, a recent survey found that $10 \%$ of remittances were devoted specifically to health care, while only $4 \%$ were destined to education (19). Yet, the majority of remittance money was still used to cover daily household expenses (73\%). This pattern is corroborated by previous research conducted with Mexican migrants (6). Second, due again to data limitations, this study did not assess the migrant experience more extensively (what has been called assimilation and diffusion) (10). However, a household-level measure of diffusion, i.e., households with international migrants, was used in this study. Future research should include, not only the economic, but the social implications of migration, for both the migrant person (41) and the recipient country, community, family, and individual, and whether gender plays a role $(24,42,43)$. Third, observable differences in health care utilization-and better health outcomes-may not be verified in the short term, since it takes time for households and communities to adapt to migration processes (6). This might be the case in Ecuador, given that $75 \%$ of its migrants left the country in 1999-2004 (31). This is corroborated by a recent study that found remittances were affecting shortand mid-term nutritional status, but not long-term anthropometric indicators-a situation that may be related to the relatively short time that households had been receiving remittances (44).

Nevertheless, with its use of both a theoretical (Andersen's model) and a multilevel statistical framework, this study adds to the growing body of literature linking migrant remittances to health care utilization and outcomes in Latin America (45). The significance of using a "social remittances" predic- tor (households with international migrants) suggests that policymakers need to incorporate migration realities into their public health and development legislation agendas, adopting a more humanistic, rather than purely economic perspective. The current government of Ecuador seems to be taking steps towards this goal by creating the National Migrant Office (Secretaría Nacional del Migrante) and by allowing migrants' representation at the National Assembly (six representatives). However, the effective translation of political representation into real benefits to migrants and their families (including access to health care) is yet to be evaluated. Overall, migration and remittances seem to have an equalizing effect on access to antiparasitic medicines and, to a lesser extent, to curative health services. Health reform efforts should take into account the scope of this effect in developing public policy.

\section{REFERENCES}

1. International Organization for Migration. Final Report on the Ministerial Conference of the Least-Developed Countries on Enhancing the Development Impact of Remittances. Geneva: IOM; 2006.

2. Gammeltoft P. Remittances and other financial flows to developing countries. International Migration. 2002;40(5):181-209.

3. World Bank. Migration and remittances. Washington, DC: World Bank; 2010.

4. Hall J. Diez años de innovación en remesas : lecciones aprendidas y modelos para el futuro. Washington, DC: Banco Interamericano de Desarrollo; 2010.

5. Terry DF, Wilson SR. Beyond small change: making migrant remittances count. Washington, D.C.: Inter-American Development Bank; 2005.

6. Durand J, Kandel W, Parrado EA, Massey DS. International migration and development in Mexican communities. Demography. 1996;33(2):249-64.

7. Roberts K, Morris MD, eds. Fortunate, risk, and remittances: an application of Options Theory to participation in village-based migration networks. Proceedings of the Annual Meeting of the Population Association of America. New Orleans; 2006.

8. Rozelle S, Taylor JE, DeBrauw A. Migration, remittances, and agriculture productivity in China. Am Econ Rev. 1999;89(2):287-91.

9. Taylor JE, Wyatt TJ. The shadow value of migrant remittances, income and inequality in a household-farm economy. J Dev Stud 1996; 32(6):899-912.

10. Lindstrom DP, Munoz-Franco E. Migration and maternal health services utilization in rural Guatemala. Soc Sci Med. 2006;63(3):706-21.
11. Frank R, Palma-Coca O, Rauda-Esquivel J, Olaiz-Fernandez G, Diaz-Olavarrieta C, Acevedo-Garcia D. The relationship between remittances and health care provision in Mexico. Am J Public Health. 2009;99(7):1227-31.

12. Edwards AC, Ureta M. International migration, remittances, and schooling: evidence from El Salvador. J Dev Econ. 2003;72(2):429-61.

13. Yang D. International migration, remittances and household investment: evidence from Philippine migrants' exchange rate shocks. Econ J. 2008;118(528):591-630.

14. Acosta P, Fajnzylber P, Lopez JH. The impact of remittances on poverty and human capital: evidence from Latin American household surveys. Washington, DC: World Bank; 2007.

15. Commission on Social Determinants of Health. Closing the gap in a generation: Health equity through action on the social determinants of health. Geneva: World Health Organization; 2008.

16. Navarro V, Shi L. The political context of social inequalities and health. Soc Sci Med. 2001; 52(3): :481-91.

17. Waters WF. Globalization and local response to epidemiological overlap in 21st century Ecuador. Global Health. 2006;2:8.

18. Pan American Health Organization. Health in the Americas: Ecuador. Washington, D.C.: PAHO; 2007. Pp. 304-21.

19. Facultad Latinoamericana de Ciencias Sociales. Ecuador: las cifras de la migración internacional. Quito: FLACSO; 2008.

20. Larrea C. Dolarización y desarrollo humano en Ecuador. Iconos. 2004;19:43-53.

21. Banco Central del Ecuador. Remesas. Available from: http://www.bce.fin.ec/frame.php?
$\mathrm{CNT}=\mathrm{ARB0000985}$ Accessed on 15 August 2010.

22. Massey DS, Parrado E. Migradollars: the remittances and savings of Mexican migrants to the United States. Popul Res Policy Rev. 1994;13:3-30.

23. Ross SJ, Pagán JA, Polsky D. Access to health care for migrants returning to Mexico. J Health Care Poor Underserved. 2006;17(2):374-85.

24. Hadi A. International migration and the change of women's position among the leftbehind in rural Bangladesh. Int J Popul Geogr. 2001;7(1):53-61.

25. Levitt P. Social remittances: migration driven local-level forms of cultural diffusion. Int Migr Rev. 1998;32(4):926-48.

26. Frank R, Hummer RA. The other side of the paradox: the risk of low-birth weight among infants of migrant and nonmigrant households within Mexico. Int Migr Rev. 2002;36(3): 746-65.

27. López-Cevallos DF, Chi C. Health care utilization in Ecuador: a multilevel analysis of socioeconomic determinants and inequality issues. Health Policy Plan. 2010;25(3):209-18.

28. Waters HR. Measuring equity in access to health care. Soc Sci Med. 2000;51(4):599-612.

29. Larrea C, Kawachi I. Does economic inequality affect child malnutrition? The case of Ecuador. Soc Sci Med. 2005;60(1):165-78.

30. Andersen RM. Revisiting the behavioral model and access to medical care: Does it Matter? J Health Soc Behav. 1995;36(1):1.

31. Centro de Estudios de Población y Desarrollo Social. Informe final: ENDEMAIN 2004. Quito, Ecuador: CEPAR; 2005.

32. Subramanian SV, Jones K, Duncan C. Multilevel methods for public health research. In: 
Kawachi I, Berkman LF, eds. Neighborhoods and health. New York: Oxford University Press; 2003. Pp. 65-111.

33. Rodriguez G, Goldman N. Improved estimation procedures for multilevel models with binary response: a case-study. J R Stat Soc Ser A Stat Soc. 2001;164(2):339-55.

34. Chaix B, Boelle P-Y, Guilbert P, Chauvin P. Area-level determinants of specialty care utilization in France: a multilevel analysis. Public Health. 2005;119(2):97-104.

35. Glei DA, Goldman N, Rodriguez G. Utilization of care during pregnancy in rural Guatemala: does obstetrical need matter? Soc Sci Med. 2003;57(12):2447-63

36. Subramanian SV, Delgado I, Jadue L, Vega J, Kawachi I. Income inequality and health: multilevel analysis of Chilean communities. J Epidemiol Community Health. 2003;57(11): 844-8.

37. Lopez-Cordova. Globalization, migration and development: the role of Mexican migrant remittances. Buenos Aires: Institute for the
Integration of Latin American and the Caribbean; 2006. [Working Paper 20].

38. Amuedo-Dorantes C, Sainz T, Pozo S. Remittances and healthcare expenditure patterns of populations in origin communities: evidence from Mexico. Buenos Aires: Institute for the Integration of Latin American and the Caribbean; 2007. [Working Paper 25].

39. Orozco M, Ferro A. Worldwide trends in international flows: 2009-2011 remittance projections. Migrant Remittances Newsletter. 2009; 7(2):1-2.

40. Orozco M. Understanding the continuing effect of the economic crisis on remittances to Latin America and the Caribbean. Washington, DC: Inter-American Development Bank; 2010.

41. Aguilera MB, Massey DS. Social capital and the wages of Mexican migrants: new hypotheses and tests. Social Forces. 2003;82(2):671-701.

42. Ramirez C, García Domínguez M, Míguez Morais J. Crossing borders: remittances, gender and development. Santo Domingo, the
Dominican Republic: United Nations International Research and Training Institute for the Advancement of Women; 2005.

43. Jokisch B, Pribilsky J. The panic to leave: economic crisis and the "new emigration" from Ecuador. Int Migr. 2002;40(4):75-102.

44. Antón J-I. The impact of remittances on nutritional status of children in Ecuador. Int Migr Rev. 2010;44(2):269-99.

45. Fajnzylber P, López JH. Close to home: the development impact of remittances in Latin America. Washington, D.C.: International Bank for Reconstruction and Development, World Bank; 2007.

Manuscript received on 28 January 2011. Revised version accepted for publication on 28 July 2011.
RESUMEN

Migración, remesas de dinero
y utilización de los servicios
de salud en el Ecuador

Palabras clave
Objetivo. Examinar la relación entre la migración, las remesas de dinero y la utilización de los servicios de atención de la salud en el Ecuador y determinar los posibles efectos equilibradores.

Métodos. A partir de los datos de la Encuesta Demográfica y de Salud Materna e Infantil (ENDEMAIN) correspondientes al 2004, se efectuó un análisis multifactorial de varios niveles para evaluar la relación de dos factores predictivos de la migración (hogares con un migrante internacional; uso de remesas de dinero de migrantes) con el uso de los servicios de atención preventiva, el número de consultas para el tratamiento de enfermedades, la hospitalización y el uso de medicamentos antiparasitarios. Se incluyeron los factores predisponentes, mediadores y de necesidad percibida pertinentes según el Modelo de Andersen de Comportamientos de Utilización de los Servicios de Atención de la Salud. También se incluyeron términos de interacción para evaluar los posibles efectos equilibradores de la migración y las remesas por grupo étnico, área de residencia y nivel económico.

Resultados. Los factores predictivos de la migración se asociaron firmemente con el uso de medicamentos antiparasitarios y, en menor grado, con las consultas para el tratamiento de enfermedades, incluso después de ajustar los datos según diversos factores predisponentes, mediadores y de necesidad percibida. Los modelos de interacción demostraron que la presencia de un migrante internacional en el grupo familiar aumentaba el uso de estos servicios en los ecuatorianos de bajos ingresos (quintiles 1 y 2). No se encontró una relación significativa entre los factores predictivos de la migración y el uso de servicios preventivos.

Conclusiones. La migración y las remesas parecen tener un efecto equilibrador sobre el acceso a los medicamentos antiparasitarios y, en menor medida, sobre los servicios de atención de la salud relacionados con el tratamiento. Las actividades de reforma sanitaria deben tener en cuenta el alcance de este efecto en la elaboración de políticas públicas.

Migración; migración internacional, tendencias; accesibilidad a los servicios de salud; análisis multinivel; política de salud; Ecuador. 